\title{
Assessment of Water Quality Index in Mahanadi and Atharabanki Rivers and Taldanda Canal in Paradip Area, India
}

\author{
Pradyusa Samantray ${ }^{* 1,2}$, Basanta K. Mishra ${ }^{3}$, Chitta R. Panda ${ }^{2}$ and Swoyam P. Rout ${ }^{1}$ \\ 1. Environmental Chemistry Laboratory, Department of Chemistry, Utkal University, \\ Bhubaneswar 751 004, Orissa, India \\ 2. Institute of Minerals and Materials Technology, (Council of Scientific and Industrial \\ Research), Bhubaneswar 751 013, Orissa, India \\ 3. Department of Chemistry, Indira Gandhi Institute of Technology, Sarang, \\ Dhenkanal 759 146, Orissa, India
}

\begin{abstract}
KEYWORDS Paradip Area. NSF Water Quality Index. Dissolved Oxygen. Biochemical Oxygen Demand. Fecal Coliform

ABSTRACT An assessment of the water quality of Mahanadi and its distributary rivers and streams, Atharabanki river and Taldanda Canal adjoining Paradip was studied in three different seasons namely summer, premonsoon and winter. Four parameters namely pH, Dissolved Oxygen, Biochemical Oxygen Demand and Fecal Coliform were considered to compute Water Quality Index based on National Science Foundation studies. Our findings highlighted the deterioration of water quality in the rivers due to industrialisation and human activities.
\end{abstract}

\section{INTRODUCTION}

Paradip Area is adjoined by water bodies in three directions namely in the North, South and East. Bay of Bengal is on the South Eastern direction whereas Mahanadi river flows on the northern side and drains from west to east. Atharabanki river is of particular importance in the study of surface water pollution because the effluents from Paradip Phosphate Ltd (PPL), Indian Farmers and Fertilisers Cooperative (IFFCO) Ltd, SKOL Breweries, sewage from PPL township and Paradip Port Trust (PPT) township are discharged into this river which ultimately joins the Mahanadi river near the confluence point in the Bay of Bengal. Due to the storage of large quantities of effluents in the delay ponds of the major industries and dumping of sludge from Paradip Port berths, the surface water of Paradip faces a serious threat (Patnaik 2005). Recently the South Korean steel giant, POSCO will be setting up a steel plant in the hinterland of Paradip with communication access from Paradip Port. The present study aims at the assessment of the water quality index in Mahanadi and Atharabaki rivers and the Taladanda canal in Paradip area before the setting of POSCO and during a phase of industrialization in Paradip area.

*Corresponding Author

E-mail: spradyusa@yahoo.com

\section{MATERIALSAND METHODS}

\subsection{Study Area}

2.1.1 Mahanadi River and its Distributaries: Mahanadi River flows through a vast stretch with numerous perennial and non-perennial streams in the study area and forms a network of large and small rivers before joining the Bay of Bengal. The river is mainly used for fishing, propagation of wild life, prawn culture, irrigation etc. The Mahanadi at this stretch is classified as "Class D" as per the best designated use of water quality. Six water samples from Mahanadi river and three water samples from its distributaries were analysed to assess the water quality of Mahanadi and its distributaries in the study area during the three seasons. The sampling location description of Mahanadi and its distributaries are given in Table 1 and shown in Figure 1

2.1.2 Taldanda Canal: Taldanda canal originates from river Mahanadi at Jobra, Cuttack and flows through the study area from west to east serving as the main source of water for irrigation, domestic and industrial requirements.

Water samples from Taldanda canal were collected from various locations namely Tirtol, Choumuhani, Bhutmundai, PPL, Atharabanki etc. Activities like fishing, bathing, washing and cleaning by inhabitants are observed in this canal. 
Table 1: Mahanadi and its distributaries

\begin{tabular}{|c|c|c|c|}
\hline River course & Location & Code & Description \\
\hline Mahanadi & Nilachal Bazar & M1 & $\begin{array}{l}\text { Sampling point is near the bridge. The main } \\
\text { activity observed in the river is fishing because of } \\
\text { backwater flow from the sea the river is salty and } \\
\text { is not used for irrigation or domestic purpose. }\end{array}$ \\
\hline Nuna & Kusunpur & M2 & $\begin{array}{l}\text { Sampling point is near the Kusunpur village. The } \\
\text { main activity observed in the river is fishing. }\end{array}$ \\
\hline Mahanadi & Musadia & M3 & $\begin{array}{l}\text { Sampling point is at Musadia village. The location } \\
\text { is in close proximity to Indian Farmers and } \\
\text { Fertilizer Cooperative Ltd. (IFFCO) }\end{array}$ \\
\hline Mahanadi & Ramnagar & M4 & $\begin{array}{l}\text { The sampling station is near Ramnagar bridge. } \\
\text { The creek is used for navigation. The water is } \\
\text { used for domestic usage like washing and cleaning. }\end{array}$ \\
\hline Mahanadi & Karnasi & M5 & $\begin{array}{l}\text { The sampling station is near Karnasi jetty bridge. } \\
\text { The creek is used for navigation. The water is } \\
\text { used for domestic usage like washing and cleaning }\end{array}$ \\
\hline Mahanadi Atharabanki Confluence & Fishery Harbour & M6 & $\begin{array}{l}\text { The sampling points is located at fishery harbour } \\
\text { where Mahanadi river confluence with Atharbanki } \\
\text { river. }\end{array}$ \\
\hline Mahanadi Sea Confluence & Nehru Bungalow & M7 & $\begin{array}{l}\text { Mahanadi opens into Bay of Bengal at this } \\
\text { sampling point }\end{array}$ \\
\hline Gobari & Jambu & M8 & $\begin{array}{l}\text { It is one of the distributary of river Mahanadi. } \\
\text { The major activities in this water are fishing and } \\
\text { natural culture of fishing is also observed in these } \\
\text { waters }\end{array}$ \\
\hline Chitrotpala & Patakura & M9 & $\begin{array}{l}\text { The sampling location is at Patakura village. } \\
\text { Agricultural activities are carried on both the } \\
\text { banks of river. This river is one of the important } \\
\text { distributary of Mahanadi. }\end{array}$ \\
\hline
\end{tabular}

The sampling location descriptions of Taldanda canal are given in Table 2 and shown in Figure 1.

2.1.3 Atharabanki River: River Atharabanki flows along the boundary wall of Paradip Phosphate Ltd (PPL) and joins river Mahanadi near its confluence with Bay of Bengal. Atharabanki river acquires special importance as it is the receiving water body for treated effluents from PPL and IFFCO and domestic sewage from PPL and IFFCO colonies and Paradip township. The sampling location description of Atharabanki river is given in Table 3 and shown in Figure1.

\subsubsection{Water Quality of Other Stream: The}

other streams in the study are Jatadhari, Mahanga river, Haldia nallah, Marshaghai canal and Mahakalpara canal. The sampling locations descriptions are given in Table 4 and shown in Figure1.

\subsection{Sampling Procedure and Sample analysis}

Surface waters were collected from all the rivers and streams on a monthly basis and segmented as per three seasons postmoonson, winter and summer for the year 2006. The samples were analysed using standard procedure (APHA

Table 2: Sampling locations - Taladanda Canal

\begin{tabular}{llrl}
\hline S. No. & Location & Code & Description \\
\hline 1 & Tirtol & T-1 & $\begin{array}{l}\text { The sampling location is near the bridge. The Canal water is } \\
\text { extensively used for irrigation. } \\
\text { The sample has been collected near the bridge. The water from this } \\
\text { stream is used for lift irrigation and fishery activities. } \\
\text { The location is near the Bhutmundai Bridge. Various activities like } \\
\text { bathing and washing are predominant in this area. The sample has } \\
\text { been collected from upstream of these activities. } \\
\text { The sampling location is located near the PPL gate on highway. } \\
\text { Activities observed are bathing, washing etc. } \\
\text { The sampling location is located in Atharbanki near beer factory. } \\
\text { Activities observed are bathing, washing etc. }\end{array}$ \\
\hline
\end{tabular}




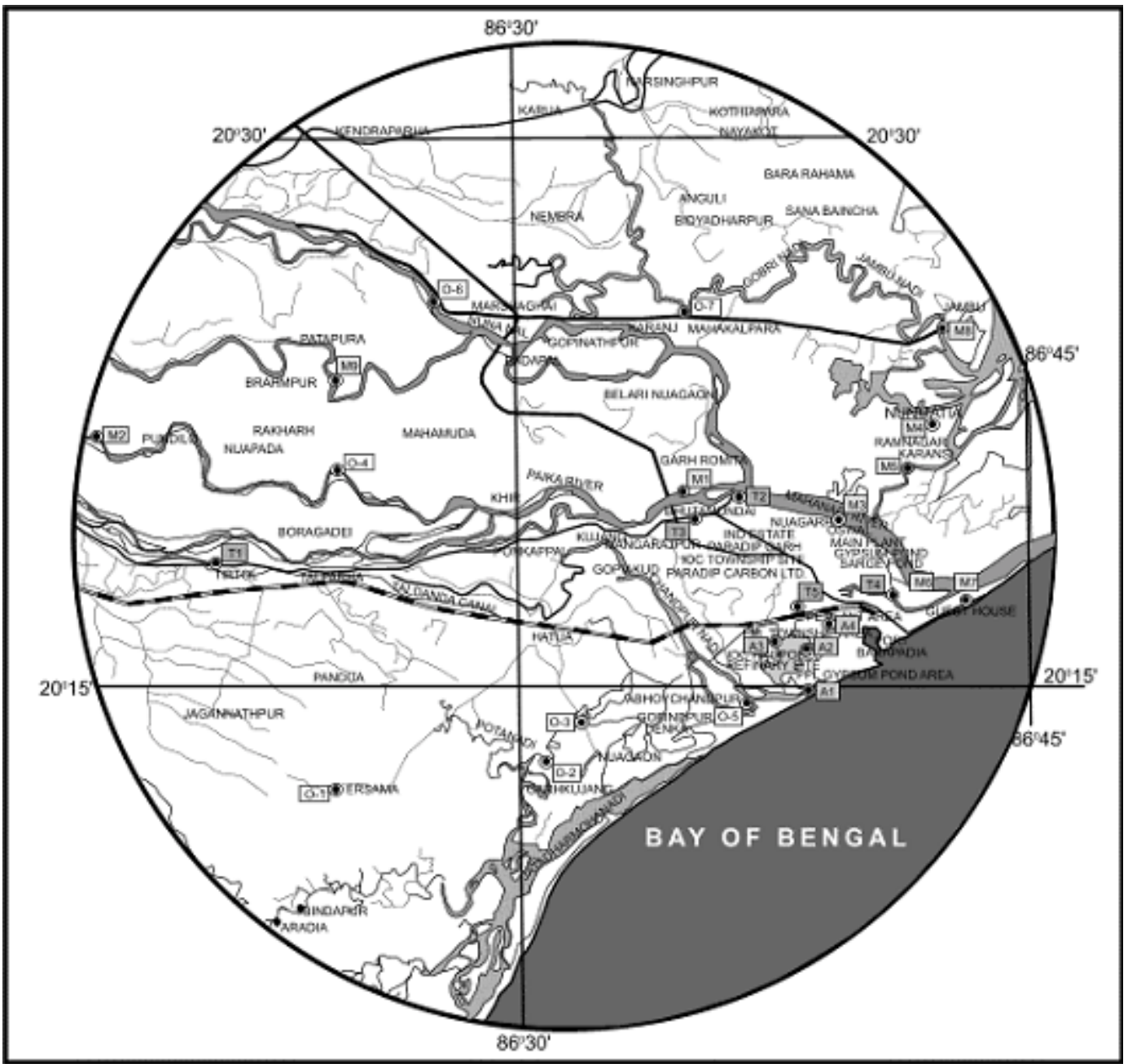

Fig. 1. Location of sampling points in Paradip area

Table 3: Sampling locations - Atharbanki River

\begin{tabular}{|c|c|c|c|}
\hline S. No. & Location & Code & Description \\
\hline 1 & Sandakud & A-1 & $\begin{array}{l}\text { The sample has been collected from Santra Nallah near Sandakud. } \\
\text { The area is located at the southwest corner of Paradip. Fisherman } \\
\text { community occupies the area and the sample collection point is in } \\
\text { one of their fishing area. Santra Nallah is tributary to Atharbanki } \\
\text { river. }\end{array}$ \\
\hline 2 & Near Gypsum Pond & A -2 & $\begin{array}{l}\text { The sampling location is close to Sandakud village. The sampling } \\
\text { point is located near the gypsum pond area of PPL towards Sandakud. }\end{array}$ \\
\hline 3 & Bhimobi Colony & A-3 & $\begin{array}{l}\text { The sampling station is located Bhimobi colony, which is the } \\
\text { upstream location for PPL waste water discharge point. }\end{array}$ \\
\hline 4 & Atharbanki & A-4 & $\begin{array}{l}\text { The sampling station is located near Atharbanki Bridge, which is } \\
\text { downstream location for PPL wastewater discharge point. }\end{array}$ \\
\hline
\end{tabular}


Table 4: Other stream-locations

\begin{tabular}{|c|c|c|c|}
\hline $\begin{array}{l}S . \\
\text { No. }\end{array}$ & River/stream & $\begin{array}{l}\text { Sampling } \\
\text { Location }\end{array}$ & Code \\
\hline 1 & Jatadhari & Erasama & $\mathrm{O}-1$ \\
\hline 2 & Mahanga River & Garh Kujang & $\mathrm{O}-2$ \\
\hline 3 & Jatadhari & Balitutha & $\mathrm{O}-3$ \\
\hline 4 & Haldia Nallah & Mangarajpur & $\mathrm{O}-4$ \\
\hline 5 & Santra Nallah & Sandakud & $0-5$ \\
\hline 6 & Marsaghai Canal & Marsaghai & $0-6$ \\
\hline 7 & Mahakalpara canal & Mahakalpara & O-7 \\
\hline
\end{tabular}

1989). The $\mathrm{pH}$ of water samples was measured in the field. Samples were subjected to filtration prior to chemical analysis. The determination of TDS was done by a gravimetric process, while the total hardness was carried out by EDTA complexometric titration method, (APHA 1989). The Winkler's method was followed for the analysis of DO and BOD. Nitrate was determined by colorimetric procedure (APHA 1989). Fecal coliform population was analysed by MPN/100ml method, by growing on M-FC medium at temperature $44.5^{\circ} \pm 1^{\circ} \mathrm{C}$ and counted after $48 \mathrm{hrs}$.

\section{RESULTS AND DISCUSSIONS}

Parameters such as pH, Dissolved Oxygen
(DO), Biochemical Oxygen Demand (BOD), Fecal Coliform have been considered out of nine parameters as the four important water quality parameters for classifications of surface water. The NSF WQI has been computed for Mahanadi river, Taldanda canal, Atharabanki river and other rivers and streams in Paradip area.

\subsection{Mahanadi River}

The water quality of Mahanadi river during different seasons are presented in Table 5 and highlighted as follow:

Postmonsoon Season: $\mathrm{pH}$ of water samples varied between 6.89 at Ramnagar to 8.08 at Kusanpur. Total Dissolved Solids (TDS) varied between $63 \mathrm{mg} / \mathrm{l}$ at Patakura to $21,771 \mathrm{mg} / \mathrm{l}$ at Nehru bungalow. Dissolved Oxygen varied between 5.9 $\mathrm{mg} / \mathrm{l}$ to $6.3 \mathrm{mg} / \mathrm{l}$. Likewise BOD values varied between $2.6 \mathrm{mg} / \mathrm{l}$ at Kusanpur to $5.8 \mathrm{mg} / \mathrm{l}$ in fishery harbour. However fluoride values are between 0.4 $\mathrm{mg} / \mathrm{l}$ to $1.42 \mathrm{mg} / \mathrm{l}$.

Winter Season: $\mathrm{pH}$ of water samples varied between 6.82 at Ramnagar to 7.81 at Kusanpur. TDS of water samples varied between $73 \mathrm{mg} / \mathrm{l}$ at Patakura to $21,782 \mathrm{mg} / \mathrm{l}$ at Nehru bungalow. However the BOD values varied between $2.7 \mathrm{mg} /$

Table 5: Water quality during different seasons- Mahanadi River

\begin{tabular}{|c|c|c|c|c|c|c|c|c|c|}
\hline Location & Season & $p H$ & $\begin{array}{c}\text { Turbidity } \\
\text { NTU }\end{array}$ & $\begin{array}{c}{[T D S]} \\
m g / l\end{array}$ & $\begin{array}{l}{[\mathrm{TH}]} \\
\mathrm{mg} / \mathrm{l}\end{array}$ & $\begin{array}{c}{\left[\mathrm{NO}_{3}\right]} \\
m \mathrm{~g} / \mathrm{l}\end{array}$ & $\begin{array}{c}{[F]} \\
m g / l\end{array}$ & $\begin{array}{c}{[B O D]} \\
m g / l\end{array}$ & $\begin{array}{c}{[\mathrm{DO}]} \\
m \mathrm{~g} / \mathrm{l}\end{array}$ \\
\hline \multirow[t]{3}{*}{ M1 } & Postmonsoon & 7.07 & 5 & 4236 & 363 & 10.8 & 1.26 & 4.7 & 6.3 \\
\hline & Winter & 7.00 & 4 & 5608 & 368 & 12.5 & 1.29 & 4.8 & 6.1 \\
\hline & Summer & 6.85 & 5 & 5633 & 388 & 15.1 & 1.31 & 5.0 & 5.9 \\
\hline \multirow[t]{3}{*}{ M2 } & Postmonsoon & 8.08 & 3 & 94 & 36 & 12.4 & 0.41 & 2.6 & 6.3 \\
\hline & Winter & 7.81 & 5 & 104 & 36 & 14.1 & 0.44 & 2.7 & 6.1 \\
\hline & Summer & 7.66 & 5 & 129 & 56 & 16.2 & 0.47 & 3.0 & 6.0 \\
\hline \multirow[t]{3}{*}{ M3 } & Postmonsoon & 7.07 & 4 & 2683 & 140 & 25.7 & 0.84 & 3.8 & 6.1 \\
\hline & Winter & 6.95 & 5 & 3734 & 140 & 27.0 & 0.87 & 3.9 & 5.9 \\
\hline & Summer & 6.81 & 6 & 3759 & 160 & 29.1 & 0.90 & 4.0 & 5.8 \\
\hline \multirow[t]{3}{*}{ M4 } & Postmonsoon & 6.89 & 4 & 5432 & 1100 & 17.6 & 1.08 & 5.7 & 5.9 \\
\hline & Winter & 6.82 & 5 & 7654 & 1125 & 19.9 & 1.11 & 5.8 & 5.7 \\
\hline & Summer & 6.67 & 5 & 9443 & 1145 & 22.0 & 1.13 & 6.0 & 5.5 \\
\hline \multirow[t]{3}{*}{ M5 } & Postmonsoon & 7.20 & 4 & 7654 & 1842 & 14.2 & 1.18 & 4.6 & 5.9 \\
\hline & Winter & 7.12 & 3 & 9876 & 1867 & 15.9 & 1.21 & 4.7 & 5.7 \\
\hline & Summer & 6.97 & 6 & 10607 & 1887 & 18.3 & 1.23 & 5.0 & 5.5 \\
\hline \multirow[t]{3}{*}{ M6 } & Postmonsoon & 6.94 & 5 & 8765 & 2548 & 30.6 & 1.25 & 5.8 & 5.9 \\
\hline & Winter & 6.89 & 7 & 9764 & 2573 & 32.3 & 1.28 & 5.9 & 5.7 \\
\hline & Summer & 6.74 & 8 & 14473 & 2593 & 35.0 & 1.30 & 6.0 & 5.5 \\
\hline \multirow[t]{3}{*}{ M7 } & Postmonsoon & 7.05 & 7 & 15765 & 4115 & 15.1 & 1.42 & 2.7 & 6.1 \\
\hline & Winter & 6.96 & 5 & 18543 & 4140 & 16.8 & 1.45 & 2.8 & 5.9 \\
\hline & Summer & 6.84 & 5 & 21907 & 4160 & 19.5 & 1.47 & 3.0 & 5.8 \\
\hline \multirow[t]{3}{*}{ M8 } & Postmonsoon & 6.98 & 5 & 16874 & 2678 & 26.9 & 1.08 & 3.8 & 6.0 \\
\hline & Winter & 6.89 & 6 & 12654 & 2703 & 29.2 & 1.11 & 3.9 & 5.9 \\
\hline & Summer & 6.78 & 6 & 19810 & 2723 & 31.3 & 1.13 & 4.0 & 5.7 \\
\hline \multirow[t]{3}{*}{ M9 } & Postmonsoon & 7.25 & 5 & 63 & 46 & 7.9 & 0.49 & 4.8 & 5.9 \\
\hline & Winter & 7.16 & 6 & 73 & 46 & 10.9 & 0.52 & 4.9 & 5.8 \\
\hline & Summer & 7.01 & 4 & 98 & 56 & 12.0 & 0.55 & 5.0 & 5.6 \\
\hline
\end{tabular}


1 at Kusanpur to $5.9 \mathrm{mg} / \mathrm{l}$ at fishery harbour. Fluoride values varied between $0.44 \mathrm{mg} / \mathrm{l}$ to 1.45 $\mathrm{mg} / \mathrm{l}$.

Summer Season: Water sample from Mahanadi river at Nilachal bazaar shows high TDS which may be due to the tidal action of the sea. In most of the stations the $\mathrm{pH}$ is nearer to 7.0 and Dissolved Oxygen $>5 \mathrm{mg} / \mathrm{l}$ indicating the healthy state of the river system. However the BOD value above $3 \mathrm{mg} / \mathrm{l}$ indicated the domestic sewage pollution throughout the river. In some stations like M-4, M-5, M-6 and M-9 the BOD values are nearer to $5 \mathrm{mg} / \mathrm{l}$, which gives a clear picture that, the river water is grossly polluted (ISI 1983; WHO 1984). In Mahanadi River system higher BOD values were recorded during summer season and such observation was also made by Das and Acharya (2003). Low concentration of BOD was recorded during post monsoon due to a huge volume of fresh water that diluted the organic matter resulting in the decrease in the BOD values (Bagde and Verma 1985; Palharya and Malvia 1988).

Water sample from Nuna Nadi a distributary of Mahanadi river near Kusanpur is within the permissible limits and may be used for domestic use after conventional treatment. BOD values of $3 \mathrm{mg} / \mathrm{l}$ showed sewage contamination through river runoff. The freshwater source of BOD in Mahanadi estuary was also reported by Panda et al. (2006).

Water sample from Mahanadi river near Musadia shows less TDS than Nilachal bazaar. The reduction in TDS may be due to dilution of the water from Nuna River.

Water sample from Mahanadi creek near
Ramnagar shows high salinity because of the inflow of sea water. BOD values are high because of contamination.

TDS in water sample at Karnasi is much higher than Ramnagar. BOD is around $5 \mathrm{mg} / \mathrm{l}$. TDS in water sample is more than $14,000 \mathrm{mg} / \mathrm{l}$ at the confluence Point of Mahanadi and Atharabanki rivers near fishery harbour and the water is saline. (Laws et al. 1998). The high BOD value is due to fishing activity.

Water sample at Nehru bungalow has high of TDS value of $21,907 \mathrm{mg} / \mathrm{l}$ and is saline. This may be due to the direct inflow of the seawater through tidal impact.

Water sample from Gobari River near Jambu a branch of Mahanadi River is highly saline due to the proximity of Jambu to the confluence point.

Water sample from Chitropala River a branch of Mahanadi River is a fresh water river. TDS is less than $100 \mathrm{mg} / \mathrm{l} \mathrm{pH}$ values varied between 6.67 to 7.66 and DO values varied between $5.5 \mathrm{mg} / \mathrm{l}$ to $6.0 \mathrm{mg} / \mathrm{l}$. Fluoride values varied between $0.47 \mathrm{mg} /$ 1 to $1.47 \mathrm{mg} / \mathrm{l}$.

\subsection{Taldanda Canal}

Taldanda canal originates from Mahanadi river at Jobra, Cuttack which is extensively used mainly for irrigation and joins Atharabanki creek at Paradip. The water quality of Taldanda canal during different seasons are presented in Table 6 and highlighted below.

Postmoonson Season: $\mathrm{pH}$ varied between 7.18 at Bhutmundai to 7.53 at PPL. BOD of water samples varied between $2.7 \mathrm{mg} / \mathrm{l}$ at Tirtol to 4.8 $\mathrm{mg} / \mathrm{l}$ at Bhutmundai. TDS at Choumuhani varied

Table 6: Water quality during different seasons - Taladanda Canal

\begin{tabular}{|c|c|c|c|c|c|c|c|c|c|}
\hline Location & Season & $p H$ & $\begin{array}{c}\text { Turbidity } \\
\quad N T U\end{array}$ & $\begin{array}{c}{[T D S]} \\
m g / l\end{array}$ & $\begin{array}{l}{[\mathrm{TH}]} \\
\mathrm{mg} / \mathrm{l}\end{array}$ & $\begin{array}{c}{\left[\mathrm{NO}_{3}\right]} \\
m g / l\end{array}$ & $\begin{array}{c}{[F]} \\
m g / l\end{array}$ & $\begin{array}{c}{[B O D]} \\
m g / l\end{array}$ & $\begin{array}{c}{[\mathrm{DO}]} \\
m g / l\end{array}$ \\
\hline \multirow[t]{3}{*}{$\mathrm{T} 1$} & Postmonsoon & 7.38 & 5 & 76 & 24 & 8.8 & 0.32 & 2.7 & 6.4 \\
\hline & Winter & 7.31 & 4 & 81 & 33 & 9.9 & 0.36 & 2.8 & 6.2 \\
\hline & Summer & 7.16 & 5 & 101 & 48 & 11.0 & 0.40 & 3.0 & 6.0 \\
\hline \multirow[t]{3}{*}{$\mathrm{T} 2$} & Postmonsoon & 7.27 & 3 & 66 & 20 & 4.0 & 0.22 & 3.6 & 6.0 \\
\hline & Winter & 7.00 & 5 & 85 & 32 & 4.5 & 0.25 & 3.7 & 5.8 \\
\hline & Summer & 6.85 & 5 & 109 & 46 & 5.0 & 0.28 & 4.0 & 5.7 \\
\hline \multirow[t]{3}{*}{ T3 } & Postmonsoon & 7.18 & 4 & 158 & 43 & 3.2 & 0.32 & 4.8 & 5.8 \\
\hline & Winter & 7.06 & 5 & 167 & 60 & 3.6 & 0.36 & 4.9 & 5.6 \\
\hline & Summer & 6.92 & 12 & 209 & 87 & 4.0 & 0.40 & 5.0 & 5.5 \\
\hline \multirow[t]{3}{*}{$\mathrm{T} 4$} & Postmonsoon & 7.53 & 4 & 184 & 63 & 5.6 & 0.24 & 3.7 & 6.0 \\
\hline & Winter & 7.46 & 5 & 194 & 98 & 6.3 & 0.27 & 3.8 & 5.8 \\
\hline & Summer & 7.31 & 4 & 242 & 140 & 7.0 & 0.30 & 4.0 & 5.6 \\
\hline \multirow[t]{3}{*}{ T5 } & Postmonsoon & 7.32 & 4 & 67 & 33 & 12.8 & 0.33 & 3.6 & 5.9 \\
\hline & Winter & 7.24 & 3 & 88 & 46 & 14.4 & 0.37 & 3.7 & 5.7 \\
\hline & Summer & 7.09 & 6 & 113 & 67 & 16.0 & 0.42 & 4.0 & 5.6 \\
\hline
\end{tabular}


between $66 \mathrm{mg} / \mathrm{l}$ to $184 \mathrm{mg} / \mathrm{l}$ at PPL. Fluoride values varied between $0.22 \mathrm{mg} / \mathrm{l}$ to $0.33 \mathrm{mg} / \mathrm{l}$. Dissolved Oxygen values varied between $5.8 \mathrm{mg} / \mathrm{l}$ to 6.4 $\mathrm{mg} / \mathrm{l}$.

Winter Season: $\mathrm{pH}$ of water samples varied between $7.0 \mathrm{mg} / \mathrm{l}$ at Choumuhani to $7.46 \mathrm{mg} / \mathrm{l}$ near PPL. BOD of water samples varied between 2.8 $\mathrm{mg} / \mathrm{l}$ at Tirtol to $4.9 \mathrm{mg} / \mathrm{l}$ at Bhutmundai.

Summer Season: $\mathrm{pH}$ of water samples varied between 6.85 at Choumuhani to 7.34 near PPL. The water quality of Taldanda canal near Tirtol is fresh water and the physico-chemical parameters are within permissible limits. TDS is about $100 \mathrm{mg} /$ 1 and BOD is very less indicating that it is free of contamination. Water samples of Taldanda canal at Choumuhani, Bhutmundai, near PPL and near Atharabanki appear to be fresh water within permissible limits.

\subsection{Atharabanki River}

The water quality of Atharabanki river at different seasons are highlighted below and presented in Table 7.

Postmoonson Season: $\mathrm{pH}$ of water samples varied between 6.45 near gypsum pond to 7.17 near Sandakud. Dissolved Oxygen values varied between $5.0 \mathrm{mg} / \mathrm{l}$ to $5.7 \mathrm{mg} / \mathrm{l}$. TDS of water samples varied between $1729 \mathrm{mg} / \mathrm{l}$ at Bhimobi colony to $5405 \mathrm{mg} / \mathrm{l}$ at Sandakud. BOD of water samples varied between $9.8 \mathrm{mg} / \mathrm{l}$ at Bhimobi colony to 17.6 $\mathrm{mg} / \mathrm{l}$ at gypsum pond. Fluoride values varied between $1.6 \mathrm{mg} / \mathrm{l}$ to $2.0 \mathrm{mg} / \mathrm{l}$.

Winter Season: $\mathrm{pH}$ of water samples varied between 6.18 near gypsum pond to 7.1 near Sandakud. BOD of water samples varied between $9.9 \mathrm{mg} / \mathrm{l}$ at Bhimobi colony to $17.7 \mathrm{mg} / \mathrm{l}$ near gypsum pond.

Summer Season: $\mathrm{pH}$ values obtained at all the sampling stations were between 5.85 and 6.95 . This arises due to contamination of gypsum pond into Atharabanki river. TDS were all higher than the permissible limits collected from Atharabanki river and may be due to seawater intrusions. (Laws et al. 1998)

Total hardness values were higher than the permissible limits in Sandakud and near gypsum pond area. Fluoride concentration was much higher than the maximum permissible limits in drinking water and is due to contamination from gypsum pond. In Atharabanki river the BOD values recorded were higher than $10 \mathrm{mg} / \mathrm{l}$ for all other sampling stations and low DO values. The low DO and high BOD in the river indicates a high organic load from the sewage of Paradip Port Township as well as effluents from fertilizer industries PPL and IFFCO situated in the upstream of the river. The influx of organic pollutants into Atharabanki river are confirmed by a high BOD and also low DO (Das et al. 1997; Pradhan et al. 1998, Nayak et al. 2001).

\subsection{Water Quality of Other Streams}

The water qualities of other streams in different seasons are highlighted below and presented in Table 8.

Postmoonson Season: The maximum TDS value of $29,640 \mathrm{mg} / \mathrm{l}$ is observed at Balitutha in Jatadhari river. DO values varied between $5.5 \mathrm{mg} /$ 1 to $6.2 \mathrm{mg} / \mathrm{l}$. BOD values varied between $2.7 \mathrm{mg} /$ 1 at Erasama in Jatadhari river to $6.4 \mathrm{mg} / \mathrm{l}$ at Sandakud in Santra nallah.

Winter Season: $\mathrm{pH}$ of water samples varied from 6.74 to 7.40. TDS value was observed to be $31,434 \mathrm{mg} / \mathrm{l}$ at Garh Kujanga in Mahanga river. BOD of water samples varied from $2.8 \mathrm{mg} / \mathrm{l}$ at Erasama in Jatadhari river to $10.7 \mathrm{mg} / \mathrm{l}$ at

Table 7: Water quality during different seasons- Atharbanki River

\begin{tabular}{|c|c|c|c|c|c|c|c|c|c|}
\hline Location & Season & $p H$ & $\begin{array}{c}\text { Turbidity } \\
\text { NTU }\end{array}$ & $\begin{array}{c}{[T D S]} \\
m g / l\end{array}$ & $\begin{array}{l}{[\mathrm{TH}]} \\
\mathrm{mg} / \mathrm{l}\end{array}$ & $\begin{array}{c}{\left[\mathrm{NO}_{3}\right]} \\
\mathrm{mg} / \mathrm{l}\end{array}$ & $\begin{array}{c}{[F]} \\
m g / l\end{array}$ & $\begin{array}{c}{[B O D]} \\
m g / l\end{array}$ & $\begin{array}{l}{[\mathrm{DO}]} \\
m \mathrm{~g} / \mathrm{l}\end{array}$ \\
\hline \multirow[t]{3}{*}{$\mathrm{T} 1$} & Postmonsoon & 7.17 & 5 & 5405 & 707 & 16.0 & 1.72 & 11.7 & 5.7 \\
\hline & Winter & 7.10 & 4 & 6552 & 989 & 18.0 & 1.94 & 11.8 & 5.5 \\
\hline & Summer & 6.95 & 6 & 8190 & 1413 & 20.0 & 2.15 & 12.0 & 5.3 \\
\hline \multirow[t]{3}{*}{$\mathrm{T} 2$} & Postmonsoon & 6.45 & 3 & 3584 & 523 & 20.0 & 1.72 & 17.6 & 5.0 \\
\hline & Winter & 6.18 & 5 & 4659 & 813 & 22.5 & 1.94 & 17.7 & 4.8 \\
\hline & Summer & 6.03 & 8 & 5973 & 1162 & 25.0 & 2.15 & 18.0 & 4.7 \\
\hline \multirow[t]{3}{*}{ T3 } & Postmonsoon & 6.63 & 4 & 1729 & 223 & 22.4 & 2.00 & 9.8 & 5.5 \\
\hline & Winter & 6.51 & 5 & 2096 & 312 & 25.2 & 2.25 & 9.9 & 5.3 \\
\hline & Summer & 6.37 & 12 & 2620 & 445 & 28.0 & 2.50 & 10.0 & 5.2 \\
\hline \multirow[t]{3}{*}{$\mathrm{T} 4$} & Postmonsoon & 6.92 & 4 & 1809 & 231 & 27.2 & 1.60 & 10.7 & 5.5 \\
\hline & Winter & 6.85 & 5 & 1904 & 359 & 30.6 & 1.80 & 10.8 & 5.3 \\
\hline & Summer & 6.70 & 5 & 2380 & 513 & 34.0 & 2.00 & 11.0 & 5.1 \\
\hline
\end{tabular}


Table 8: Water quality during different season- Other River

\begin{tabular}{|c|c|c|c|c|c|c|c|c|c|}
\hline Location & Season & $p H$ & $\begin{array}{c}\text { Turbidity } \\
\text { NTU }\end{array}$ & $\begin{array}{c}{[T D S]} \\
m g / l\end{array}$ & $\begin{array}{l}{[\mathrm{TH}]} \\
\mathrm{mg} / \mathrm{l}\end{array}$ & $\begin{array}{c}{\left[\mathrm{NO}_{3}\right]} \\
m g / l\end{array}$ & $\begin{array}{c}{[F]} \\
m g / l\end{array}$ & $\begin{array}{c}{[B O D]} \\
m g / l\end{array}$ & $\begin{array}{l}{[D O]} \\
m g / l\end{array}$ \\
\hline \multirow[t]{3}{*}{ O-1 } & Postmonsoon & 7.37 & 5 & 345 & 51 & 4.8 & 0.36 & 2.7 & 6.2 \\
\hline & Winter & 7.30 & 4 & 364 & 72 & 5.4 & 0.40 & 2.8 & 6.0 \\
\hline & Summer & 7.15 & 4 & 455 & 103 & 6.0 & 0.45 & 3.0 & 5.8 \\
\hline \multirow[t]{3}{*}{$\mathrm{O}-2$} & Postmonsoon & 7.01 & 3 & 24180 & 2700 & 1.6 & 1.12 & 3.6 & 5.9 \\
\hline & Winter & 6.74 & 5 & 31434 & 4200 & 1.8 & 1.26 & 3.7 & 5.7 \\
\hline & Summer & 6.59 & 6 & 40300 & 6000 & 2.0 & 1.40 & 4.0 & 5.6 \\
\hline \multirow[t]{3}{*}{$\mathrm{O}-3$} & Postmonsoon & 7.00 & 4 & 29640 & 2750 & 2.4 & 0.96 & 2.8 & 6.1 \\
\hline & Winter & 6.88 & 5 & 31200 & 3850 & 2.7 & 1.08 & 2.9 & 5.9 \\
\hline & Summer & 6.74 & 6 & 39000 & 5500 & 3.0 & 1.20 & 3.0 & 5.8 \\
\hline \multirow[t]{3}{*}{$\mathrm{O}-4$} & Post monsoon & 7.23 & 4 & 1223 & 144 & 3.2 & 0.42 & 3.7 & 5.9 \\
\hline & Winter & 7.16 & 5 & 1288 & 224 & 3.6 & 0.47 & 3.8 & 5.7 \\
\hline & Summer & 7.01 & 8 & 1610 & 320 & 4.0 & 0.53 & 4.0 & 5.5 \\
\hline \multirow[t]{3}{*}{ O-5 } & Postmonsoon & 7.26 & 4 & 3580 & 527 & 6.4 & 1.34 & 10.6 & 5.5 \\
\hline & Winter & 7.18 & 3 & 46554 & 738 & 7.2 & 1.51 & 10.7 & 5.3 \\
\hline & Summer & 7.03 & 4 & 5967 & 1055 & 8.0 & 1.68 & 11.0 & 5.2 \\
\hline \multirow[t]{3}{*}{ O-6 } & Postmonsoon & 7.36 & 4 & 112 & 42 & 1.6 & 0.36 & 7.8 & 5.6 \\
\hline & Winter & 7.24 & 5 & 136 & 59 & 1.8 & 0.40 & 7.9 & 5.4 \\
\hline & Summer & 7.10 & 12 & 170 & 85 & 2.0 & 0.45 & 8.0 & 5.3 \\
\hline \multirow{3}{*}{ O-7 } & Postmonsoon & 7.47 & 4 & 121 & 38 & 2.4 & 0.32 & 4.7 & 5.8 \\
\hline & Winter & 7.40 & 5 & 128 & 59 & 2.7 & 0.36 & 4.8 & 5.6 \\
\hline & Summer & 7.25 & 28 & 160 & 85 & 3.0 & 0.40 & 5.0 & 5.4 \\
\hline
\end{tabular}

Sandakud in Santra nallah. However fluoride values varied from $0.36 \mathrm{mg} / \mathrm{l}$ to $1.51 \mathrm{mg} / \mathrm{l}$.

Summer Season: TDS was observed to be more in water samples collected at Jatadhari in Mahanga river from Garh Kujang and Balitutha. The total hardness value was maximum of $85 \mathrm{mg} /$ 1 at Marshaghai and Mahakalpara canals. But the total hardness was maximum at 6000 and 5500 $\mathrm{mg} / \mathrm{l}$ respectively at Garh Kujanga and Balitutha. Dissolved Oxygen values varied from $5.2 \mathrm{mg} / \mathrm{l}$ to $5.8 \mathrm{mg} / \mathrm{l}$.

\subsection{National Sanitation Foundation Water Quality Index (NSF WQI)}

NSF WQI is an excellent management and general administrative tool in communicating water quality information. This index has been widely field tested and applied to data from a number of different geographical areas all over the world in order to calculate Water Quality Index (WQI) of various water bodies critical pollution parameters were considered.

The mathematical expression for NSF WQI is given by

$$
\text { NSF WQI }=\sum_{i=1}^{p} W_{i} I_{i}
$$

Where

$I_{i}$ is the sub-index for $i_{\text {th }}$ water quality parameters
$\mathrm{W}_{\mathrm{i}}$ is the weight (in terms of importance) associated with $\mathrm{i}_{\text {th }}$ water quality parameter

$p$ is the number of water quality parameters

NSF WQI of Taldanda, Mahanadi, and Atharabanki and for other rivers and streams are depicted in Table 9 and Table 10. The classification criteria standards based on NSF WQI are given in Table 11. The following observations were made based on the National Sanitation Foundation Water Quality Index of various water bodies in the study area.

The quality of Mahanadi and its distributaries are good and fall under " $\mathrm{B}$ " category, except at Ramnagar where the water quality is medium and falls under "C" category. The quality of Taldanda canal is good and belongs to "B" category. Atharabanki river has medium water quality except at sampling point near gypsum pond of PPL where it is having poor water quality and the river is classified as "C-D" category. The water quality of Mahanga river, Haldia nallah, Santra nallah, Marsaghai canal and Mahakalpara stream are observed to be of medium quality and classified as "C" category. However the sample collected from Jatadhari river is of good quality and is classified as "B" category.

Among all the sampling areas i. e. Taladanda canal, Mahanadi river, Atharabanki river and other rivers the water quality of the Atharabanki river is the most polluted as the NSF WQI is the lowest (Fig. 2,3) 
Table 9: NSF WQI - Taladanda, Mahanadi and Atharbanki rivers

\begin{tabular}{|c|c|c|c|c|c|c|c|c|}
\hline $\begin{array}{l}S . \\
N o .\end{array}$ & Sampling point & $p H$ & $\begin{array}{c}D O \\
m g / l\end{array}$ & $\begin{array}{l}B O D \\
m g / l\end{array}$ & $\begin{array}{c}F C, \\
M P N / 100 m l\end{array}$ & $\begin{array}{l}N S F \\
W Q I\end{array}$ & Description & Class \\
\hline \multicolumn{9}{|c|}{ Taladanda Canal } \\
\hline 1 & Tirtol & 7.16 & 6.0 & 3 & 1 & 81 & Good & B \\
\hline 2 & Choumuhani & 6.85 & 5.7 & 4 & 1 & 76 & Good & B \\
\hline 3 & Bhutamundai & 6.92 & 5.5 & 5 & 2 & 72 & Good & B \\
\hline 4 & PPL & 7.31 & 5.6 & 4 & 1 & 79 & Good & B \\
\hline 5 & Atharbanki & 7.09 & 5.6 & 4 & 1 & 77 & Good & B \\
\hline \multicolumn{9}{|c|}{ Mahanadi River } \\
\hline 1 & Nilachal Bazar & 6.85 & 5.9 & 5 & 2 & 73 & Good & B \\
\hline 2 & Kusunpur & 7.66 & 5.9 & 5 & 7 & 75 & Good & B \\
\hline 3 & Musadia & 6.81 & 5.8 & 4 & 4 & 71 & Good & B \\
\hline 4 & Ramnagar & 6.67 & 5.5 & 6 & 9 & 64 & Medium & $\mathrm{C}$ \\
\hline 5 & Karnasi & 6.97 & 5.6 & 5 & 3 & 71 & Good & B \\
\hline 6 & Fishery Harbour & 6.74 & 5.5 & 6 & 1 & 72 & Good & B \\
\hline 7 & Nehru bungalow & 6.84 & 5.8 & 3 & 1 & 77 & Good & B \\
\hline 8 & Jambu & 6.78 & 5.7 & 4 & 1 & 75 & Good & B \\
\hline 9 & Patakura & 7.01 & 5.6 & 5 & 3 & 72 & Good & B \\
\hline \multicolumn{9}{|c|}{ Atharbanki River } \\
\hline & ndakud & 6.95 & 5.3 & 12 & 12 & 59 & Medium & $\mathrm{C}$ \\
\hline & ar Gypsum Pond & 6.03 & 4.7 & 18 & 15 & 48 & $\mathrm{Bad}$ & $\mathrm{D}$ \\
\hline & imobi Colony & 6.37 & 5.2 & 10 & 18 & 53 & Medium & $\mathrm{C}$ \\
\hline & harbanki & 6.70 & 5.1 & 11 & 25 & 54 & Medium & $\mathrm{C}$ \\
\hline
\end{tabular}

Table 10: NSF WQI - Other rivers in the study area

\begin{tabular}{|c|c|c|c|c|c|c|c|c|c|}
\hline \multicolumn{2}{|c|}{$\begin{array}{l}\text { S. River/stream } \\
\text { No. }\end{array}$} & \multirow{2}{*}{$\begin{array}{l}\text { Location } \\
\text { Erasama }\end{array}$} & \multirow{2}{*}{$\begin{array}{c}p H \\
7.15\end{array}$} & \multirow{2}{*}{$\begin{array}{r}\begin{array}{c}D O \\
m g / l\end{array} \\
5.8\end{array}$} & \multirow{2}{*}{$\begin{array}{r}\text { BOD } \\
m g / l\end{array}$} & \multirow{2}{*}{$\begin{array}{c}F C, \\
M P N / 100 m l\end{array}$} & \multirow{2}{*}{$\begin{array}{r}N S F \\
W Q I \\
72\end{array}$} & \multirow{2}{*}{$\begin{array}{c}\text { Description } \\
\text { Good }\end{array}$} & \multirow{2}{*}{$\begin{array}{r}\text { Class } \\
\mathrm{B}\end{array}$} \\
\hline$\overline{1}$ & Jatadhari & & & & & & & & \\
\hline 2 & Mahanga River & Garh Kujang & 6.59 & 5.6 & 4 & 10 & 66 & Medium & $\mathrm{C}$ \\
\hline 3 & Jatadhari & Balitutha & 6.74 & 5.8 & 3 & 9 & 70 & Medium & $\mathrm{C}$ \\
\hline 4 & Haldia nallah & Mangarajpur & 7.01 & 5.5 & 4 & 12 & 68 & Medium & $\mathrm{C}$ \\
\hline 5 & Santra nallah & Sandakud & 7.03 & 5.2 & 11 & 18 & 58 & Medium & $\mathrm{C}$ \\
\hline 6 & Marsaghai canal & Marsaghai & 7.10 & 5.3 & 8 & 20 & 61 & Medium & $\mathrm{C}$ \\
\hline 7 & Mahakalpara canal & Mahakalpara & 7.45 & 5.4 & 5 & 22 & 66 & Medium & $\mathrm{C}$ \\
\hline
\end{tabular}

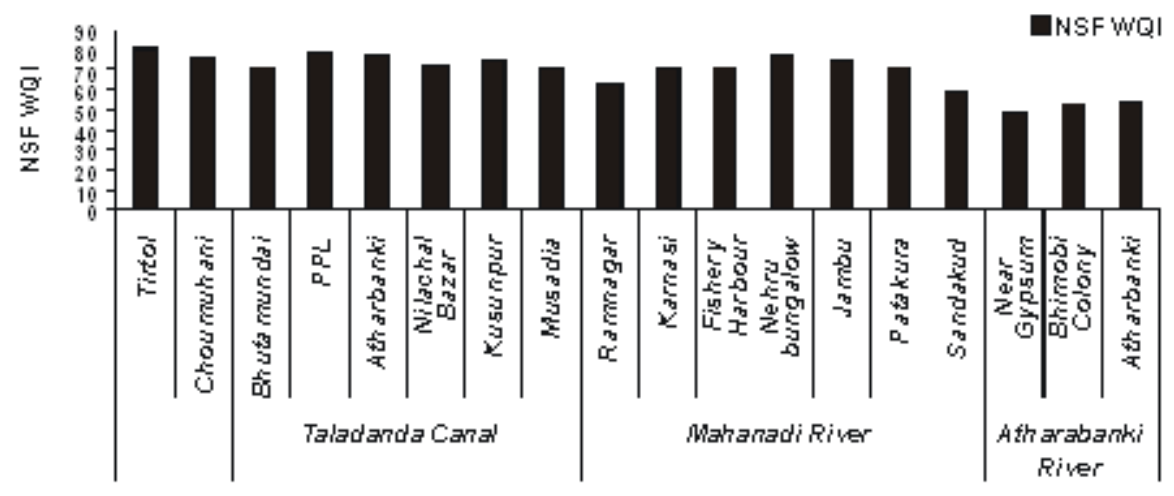

Locations

Fig. 2. NSF WQI of Taldanda Canal, Mahanadi River and Atharabanki River in Paradip Area 


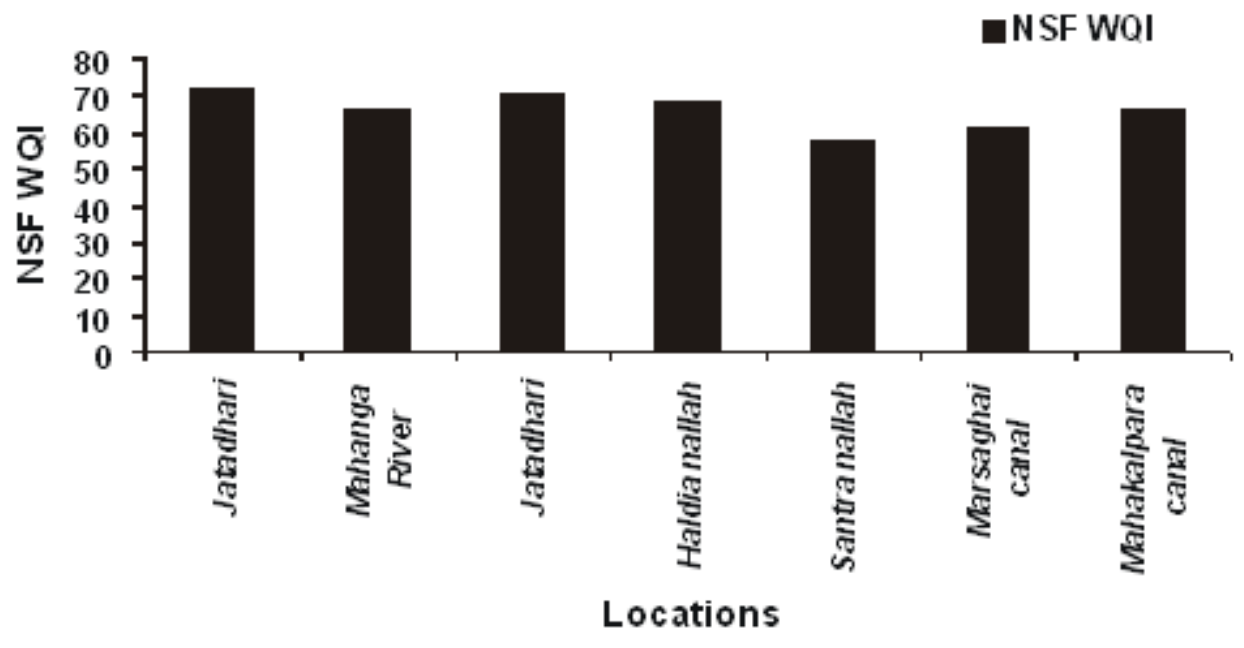

Fig. 3. NSF WQI of other Rivers in Paradip Area

Table 11: Classification criteria standards based on NSF- WQI

\begin{tabular}{llc}
\hline$N S F-W Q I$ & Descriptor & Category \\
\hline $91-100$ & Excellent & $\mathrm{A}$ \\
$71-90$ & Good & $\mathrm{B}$ \\
$51-70$ & Medium & $\mathrm{C}$ \\
$26-50$ & Bad & $\mathrm{D}$ \\
$0-25$ & Very Bad & $\mathrm{E}$ \\
\hline
\end{tabular}

\section{CONCLUSION}

We have studied the National Sanitation Foundation Water Quality Index of various water bodies in sampling areas i.e. Taladanda canal, Mahanadi river, Atharabanki river of Paradip, India in different seasons. The water quality of the Atharabanki river is found to be the most polluted.

\section{REFERENCES}

APHA 1989. Standards Methods for the Examination of Water and Wastewater. 17 $7^{\text {th }}$ Edn., Washington, D.C.: APHA, AWWA, WPFC, 2005.

Bagde US, Verma AK 1985, Limnological studies of JNU lake, New Delhi. Proc Natl Sump Pure and Appld Limnl, 32: 16-23.

Das J, Das SN, Sahoo RK 1997. Semidiurnal variation of some physico-chemical parameters in the Mahanadi estuary, East Cost of India. Indian J Mar Sci, 26: 323-326.

Das J, Acharya BC 2003. Hydrology and Assessment of Lotic Water Quality in Cuttack City, India. Water, Air and Soil Pollution, 150: 163-175.

ISI 1983. Indian Standard: Specification for Drinking Water. New Delhi India: Indian Standards Institution.

Laws EA, Ziemann D, Schulamn D 1998. Coastal water quality in Hawaii: the importance of buffer zones and dilution. Mar Environ Res, 48: 1-21.

Nayak BB, Sahoo BN, Acharya BC, Sahoo RK 1997. Studies on water and sediment qualities around Dhamara Estury, Orissa. Vistas goel Res Utkal Univ Spl Publ Goel, 2: 243-250.

Palharya JP, Malvia S 1998. Pollution of Narmada river at Hoshangabad in Madhya Pradesh and Suggested Measure for Control. In: RK Trivedy (Ed.): Ecology and Pollution of Indian Rivers. New Delhi: Ashish Publishing House, pp. 55-85.

Panda UC, Sundaray SK, Ratha P, Nayak BB, Bhatta D 2006. Application of factor and cluster analysis for characterization of river and estuarine water systems - A case study: Mahanadi River (India). Journal of Hydrology, 331: 434-445.

Patnaik KN 2005. Studies on Environmental Pollution of Major Industries in Paradip Area. PhD Thesis (Unpublished), Bhubneshwar: Utkal University.

Pradhan SK, Patnaik D, Rout SP 1998. Ground water quality - an assessment around a phosphatic fertilizer plant at paradip. Indian J Environ Protect 18(10): 769-772.

WHO (World Health Organisation) 1984. Guidelines for Drinking Water Quality. Vol. 1, Health Criteria and Other Supporting Information. Geneva: WHO. 